\title{
Correction: Pro-con debate on regionalization of emergency general surgery: controversy or common sense?
}

Santry H, Kao LS, Shafi S, et al. Pro-con debate on regionalization of emergency general surgery: controversy or common sense? Trauma Surgery \& Acute Care Open 2019;4:e000319. doi: 10.1136/tsaco-2019-000319.

The publisher wishes to note that the published article contains a dead link to the recording of the Lunch Session for the American Association for the Surgery of Trauma's 2018 Annual Meeting. The video can now be found at https://brightcove.hs.llnwd.net/v1/uds/pd/ 2696240571001/201911/1172/2696240571001_6107074733001_6107071424001.mp4? pubId $=2696240571001 \&$ videoId $=6107071424001$. This correction does not change the results or conclusions of the study.

\section{(2) \\ OPEN ACCESS}

Open access This is an open access article distributed in accordance with the Creative Commons Attribution Non Commercial (CC BY-NC 4.0) license, which permits others to distribute, remix, adapt, build upon this work noncommercially, and license their derivative works on different terms, provided the original work is properly cited, appropriate credit is given, any changes made indicated, and the use is non-commercial. See: http://creativecommons.org/licenses/by-nc/ $4.0 \%$.

(C) Author(s) (or their employer(s)) 2019. Re-use permitted under CC BY-NC. No commercial re-use. See rights and permissions. Published by BMJ.

Trauma Surg Acute Care Open 2019;4:e00319corr1. doi:10.1136/tsaco-2019-000319corr1

A) Check for updates 